19. Реєнт О. П., Ткаченко В. М. Україна на межі цивілізацій: іст.-політол. розвідки. Київ: Ін-т історії України НАН України, 1995. 159 с.

20. Селіванов В. Правовий прогрес України. Методологічні проблеми дослідження. Віче. 1998. № 1. С. 40-61.

21. Пахомов Ю. Реформи в Україні та Східній Європі. Розбудова держави. 1998. № 5-6. C. 67-72.

22. Шаповал В. Теоретичні проблеми реалізації норм Конституції України. Право України. 1997. № 6. С. 6-10.

23. Hoffmann H. Human rights and the House of Lords. The Modern Law Review. March 1999. V. 62. № 2. P. 166.

24. Скрипнюк О. В. Соціальна, правова держава в Україні: проблеми теорії і практики. До 10-річчя незалежності України: монографія. Київ: Інститут держави і права ім. В. М. Корецького НАН України, 2000. 600 с.

DOI 10.31558/2518-7953.2019.2.3

УДК 342.5

Н. М. Кошіль,

суддя Катеринопільського районного суду

Черкаської області, кандидат юридичних наук

\title{
ПРИНЦИП ПРАВОВОЇ ВИЗНАЧЕНОСТІ У ДІЯЛЬНОСТІ СУДІВ ТА ІНШИХ ОРГАНІВ ДЕРЖАВНОЇ ВЛАДИ
}

Ключові слова: принципи права, принципи конституціоналізму, основні принципи права, суд, судовий розгляд, принцип правової визначеності, принцип юридичної визначеності.

Наразі в Україні багато уваги привертають до себе актуальні питання, пов'язані з діяльністю судів. Судові рішення інколи викликають нарікання, що може бути пов'язано з недотриманням низки важливих принципів у процесі їхнього прийняття. Зокрема, варто звернути увагу на проблему дотримання у процесі судочинства принципів, про які неодноразово згадується у рішеннях Європейського суду $з$ прав людини. Часто ця проблема полягає у тому, що тривале антидемократичне минуле України обумовило відсутність як належного розуміння сутності та змісту цих принципів, так і відсутність традицій їхнього застосування. Ці принципи є відносно новими для України, а тому важко переоцінити актуальність дослідження їхньої сутності та змісту.

Одним $з$ таких принципів $є$ принцип правової визначеності. Він є надзвичайно важливим для захисту прав як фізичних, так і юридичних осіб, зокрема у судах. Однак в аспекті аналізу практики Свропейського суду з прав людини щодо 
принципу правової визначеності акцент робиться на захисті прав і свобод саме фізичних осіб.

Низка фахівців з теорії права, конституційного та інших галузей права досліджували як принципи права загалом, так і принцип правової визначеності. Серед монографічних досліджень у цій сфері варто зауважити дисертації А. М. Колодія на тему «Конституційний розвиток принципів права України (методологічні питання)» (м. Київ, 1999 р.), а також С. П. Погребняка на тему «Основоположні принципи права» (м. Харків, 2009 р.). Також варто зазначити численні статті, присвячені принципу правової визначеності, наприклад, таких авторів, як-от Л. Л. Богачова, С. П. Головатий, А. М. Приймак, П. М. Рабінович, М. В. Савчин та інші. Однак, багато вчених розглядають важливість принципу правової визначеності лише у правозастосовній діяльності судів, у той час як він має і більш широке значення [1;2].

Метою ияієї статті є з'ясування сутності та змісту принизипу правової визначеності на основі дослідження практики Свропейського суду з прав людини.

Принцип правової визначеності є доволі новим для України. Зокрема за часів перебування Української Радянської Соціалістичної Республіки у складі СРСР цей принцип у своєму сучасному розумінні не знаходив свого повного та адекватного сутнісного та змістовного розкриття у діяльності органів державної влади. I тільки після проголошення незалежності цей принцип став набувати важливого характеру.

Не в останню чергу це відбувається тому, що принцип правової визначеності привертає пильну увагу органів Ради Європи. Наприклад, щодо цього принципу у Доповіді «Верховенство права», схваленій Європейською Комісією «За демократію через право» (Венеціанською Комісією) на 86-му пленарному засіданні (Венеція, 25-26 березня 2011 р.) зазначено таке:

- «принцип правової визначеності є ключовим у питанні довіри до судової системи і верховенства права;

- для досягнення цієї довіри держава повинна складати тексти законів так, щоб вони були доступними;

- держава також зобов'язана дотримуватися та застосовувати у прогнозований і послідовний спосіб ті закони, які вона ввела в дію;

- прогнозованість означає, що закон повинен, коли це можливо, бути оприлюдненим до його виконання і бути передбачуваним у тому, що стосується його наслідків: він має бути сформульований достатньо точно для того, щоб людина могла регулювати свою поведінку» [3].

Принцип правової визначеності найбільш яскраво проявляється у діяльності Свропейського суду з прав людини. Фактично, Свропейський суд з прав людини «виводить» цей принцип зі змісту Конвенції про захист прав людини і осново- 
положних свобод 1950 р. та послідовно захищає його, водночас розкриваючи все нові й нові грані його сутності та змісту. Розуміння сутності та змісту цього принципу не є статичним, воно постійно еволюціонує, здебільшого завдяки юридичним позиціям Європейського суду з прав людини.

Свропейський суд з прав людини застосовує принцип правової визначеності настільки часто та настільки ефективно, що він починає асоціюватися виключно 3 принципами судочинства. Водночас, саме з рішень Європейського суду з прав людини випливають і інші складові сутності та змісту цього принципу. А втім, вони часто залишаються поза увагою дослідників та практичних працівників. Тут потрібно зазначити, що практика Свропейського суду з прав людини нараховує тривалий період, а Україна долучилася до цінностей та принципів, які знаходять своє відбиття у рішеннях та постановах цього органу, лише трохи більше, ніж два десятиріччя тому.

Європейський суд з прав людини згадував про принцип правової визначеності у контексті справ щодо України. Варто звернути особливу увагу на такі рішення:

- від 6 листопада 2008 р. у справі «Слоєв проти України» (Заява № 17283/02);

- від 18 грудня 2008 р. у справі «Новік проти України» (Заява № 48068/06).

У справі «Єлоєв проти України» заявник оскаржував законність та тривалість досудового тримання під вартою та надмірність тривалості провадження у його кримінальній справі за ухилення від сплати податків. У параграфі 53 Рішення зазначено: «Суд також нагадує, що практика, яка виникла внаслідок законодавчої прогалини і яка зумовлює тримання особи під вартою протягом необмеженого і непередбачуваного строку, за обставин, коли таке тримання не передбачається ні конкретним положенням законодавства, ні будь-яким судовим рішенням, сама по собі суперечить принципу юридичної визначеності, який імплікований Конвенцією і який становить один із основних елементів верховенства права» [4]. Свропейський суд 3 прав людини при цьому посилається на справи «Барановський проти Польщі» (Baranowski v. Poland), № 28358/95, п. 55, ECHR 2000-III, i «Кавка проти Польщі» (Kawka v. Poland), № 25874/94, п. 51, від 9 січня 2001 р.

У рішенні у справі «Новік проти України» заявник скаржився на своє затримання працівниками міліції на підставі його знаходження у міжнародному розшуку з метою подальшої видачі зарубіжній країні. У цьому рішенні Свропейський суд з прав людини у параграфі 19 підкреслив: «коли йдеться про позбавлення свободи, надзвичайно важливою умовою $є$ забезпечення загального принципу юридичної визначеності. Вимога «якості закону» у розумінні п. 1 ст. 5 Конвенції означає, що коли національний закон передбачає можливість позбавлення свободи, такий закон має бути достатньо доступним, чітко сформульованим і передбачуваним у своєму застосуванні - для того, щоб виключити будь-який ризик свавілля» [5]. Свропейський суд з прав людини при цьому посилається на справи 
«Барановський проти Польщі» (Baranowski v. Poland), № 28358/95, пп. 50-52, ECHR 2000-III, і «Худойоров проти Рociï» (Khudoyorov v. Russia), № 6847/02, п. 125, ECHR 2005-X.

Варто підкреслити, що принцип правової визначеності є важливим та значущім сам по собі. Але його вагомість серед інших принципів зростає тому, що, як цілком правильно зазначив С. П. Погребняк, принцип правової визначеності «виявляє себе не тільки на етапі правотворчості, а й на етапі правозастосування. Отже, пропонується виокремлювати дві групи вимог, які походять 3 цього принципу: вимоги до нормативно-правових актів і вимоги до їхнього застосування» [6, c. 181-192]. Вчений також погоджується з тим, що «принцип правової визначеності покликаний гарантувати ефективну дію принципу верховенства права» [6, с. 38].

Зв’язок між принципом верховенства права та принципом правової визначеності підкреслювали і Конституційний Суд України, і Свропейський суд з прав людини. Сдиний орган конституційної юрисдикції зазначив про наявність такого зв'язку в одному з рішень Свропейського суду з прав людини у справі за участю України. «Так, у справі «Пономарьов проти України» Європейський суд з прав людини наголосив, що «право на справедливий судовий розгляд, яке гарантовано п. 1 ст. 6 Конвенції про захист прав людини і основоположних свобод 1950 р., має розумітися у світлі преамбули Конвенції, у відповідній частині якої зазначено, що верховенство права є спільною спадщиною Високих Договірних Сторін. Одним з фундаментальних аспектів верховенства права є принцип правової визначеності, який передбачає повагу до принципу res judicata - принципу остаточності рішень суду. Цей принцип стверджує, що жодна зі сторін не має права вимагати перегляду остаточного та обов'язкового рішення суду просто тому, що вона має на меті добитися нового слухання справи та нового ії вирішення» (параграф 40) [7].

Це Рішення Конституційного Суду України - Рішення у справі за конституційним поданням 46 народних депутатів України щодо офіційного тлумачення термінів «найвищий судовий орган», «вищий судовий орган», «касаційне оскарження», які містяться у ст.ст. 125, 129 Конституції України від 11 березня 2010 р. № 8-рп/2010 - вбачається менш вагомим з точки зору розуміння змісту принципу правової визначеності у широкому розумінні. У п. 3.4 цього рішення йдеться про цей принцип, але у його вузькому значенні: «Касаційна інстанція реалізує свої процесуальні права в межах касаційного провадження виключно для перевірки правильності юридичної оцінки обставин справи у рішеннях судів першої та апеляційної інстанцій. Як касаційна інстанція Верховний Суд України повторно після вищих судів перевіряє рішення судів (ст.ст. 39, 47 Закону України «Про судоустрій України», розділ ХІІ ${ }^{2}$ Господарського процесуального кодексу України, ч. 2 ст. 235 Кодексу адміністративного судочинства України), що не може 
бути виправдано з точки зору забезпечення права на справедливий розгляд справи упродовж розумного строку. Крім того, наявність двох касаційних інстанцій для перевірки рішень спеціалізованих судів не відповідає засадам правової визначеності» [7].

Повертаючись до зазначених вище рішень Свропейського суду з прав людини у справах за участю України, у яких згадується про принцип правової визначеності, варто підкреслити: хоча ці рішення не належать до числа тих, які цитуються зарубіжними вченими серед основних рішень, у яких Суд розкриває сутність і зміст та удосконалює розуміння принципу правової визначеності. Також Європейський суд з прав людини при кожній згадці про цей принцип надає посилання на інші справи, розглянуті раніше, у такий спосіб демонструючи послідовність своєї позиції та контінуїтет. Надзвичайно важливо підкреслити, що «ключові» рішення щодо принципу правової визначеності не належать до числа рішень у спорах, де однією зі сторін була Україна. Це може свідчити про те, що принцип правової визначеності втілюється в Україні доволі послідовно. У цьому контексті варто відзначити, що єдиний орган конституційної юрисдикції - Конституційний Суд України, - докладає значних зусиль для привернення уваги до принципу правової визначеності. Це знаходить свій прояв у тому, що в рішеннях цього органу наявні посилання на цей принцип, Суд послідовно дотримується його при вирішенні відповідних справ (наприклад, рішення у справі про постійне користування земельними ділянками від 22 вересня 2005 р. № 5-рп/2005, п. 5.4 [8], рішення у справі за конституційним поданням Уповноваженого Верховної Ради України з прав людини щодо відповідності Конституції України (конституційності) абз. 8 п. 5 ч. 1 ст. 11 Закону України «Про міліцію» від 29 червня 2010 р. № 17-рп/2010, абз. 3 п. 3.1 [9], рішення у справі за конституційним поданням 49 народних депутатів України щодо відповідності Конституції України (конституційності) п. 7 ч. 2 ст. 42 Закону України «Про вищу освіту» від 20 грудня 2017 р. № 2-p/2017, п. 2.1 [10]). В останньому Рішенні єдиний орган конституційної юрисдикції сформулював, що «принцип правової визначеності вимагає чіткості, зрозумілості й однозначності правових норм, зокрема їхньої передбачуваності (прогнозованості) та стабільності» [10].

Варто погодитися 3 Л. Л. Богачовою в тому, що «у широкому розумінні принцип правової визначеності є сукупністю вимог до організації та функціонування правової системи з метою забезпечення стабільного правового положення людини шляхом вдосконалення процесів правотворчості та правозастосування» [11]. У цьому контексті доцільно навести ще одне рішення Конституційного Суду України - Рішення у справі про Регламент Верховної Ради України від 1 квітня 2008 р. № 4-рп/2008. У п. 4.1. цього Рішення єдиний орган конституційної юрисдикції зазначив, що «державна влада в Україні здійснюється на засадах 
iï поділу на законодавчу, виконавчу та судову (ч. 1 ст. 6 Конституції України). Поділ державної влади є структурною диференціацією трьох рівнозначних основних функцій держави: законодавчої, виконавчої, судової. Він відбиває функціональну визначеність кожного з державних органів, передбачає не тільки розмежування їхніх повноважень, а й їхню взаємодію, систему взаємних стримувань та противаг, які мають на меті забезпечення їхнього співробітництва як єдиної державної влади» [12]. Отже, єдиний орган конституційної юрисдикції в Україні зробив важливий крок у напрямі привернення уваги до того, що принцип правової визначеності (певності) має не один, а два аспекти свого змісту - вузький та широкий. I принцип правової визначеності у широкому розумінні є надзвичайно важливим.

Резюмуючи, варто зазначити, щуо дотримання принщуипу правової визначеності є надзвичайно важливим для захисту прав і свобод осіб, щзо звертаються до судів. Низка рімень Свропейського суду з прав людини свідчить про те, щуо у судовому прочесі розкриваються такі складові цъього принциипу, як чітке формулювання причини, на підставі якої особа обмежується у свободі чи позбавляється ї̈, неможливість скасування остаточного судового рішення тощу. Водночас, акцент на судово-процесуальний зміст изього принципу часто надає підстави ігнорувати значущість його дотримання також і органами інших гілок влади законодавчої, виконавчої. А тому потрібно звертати увагу на зміст принципу правової визначеності саме у широкому, а не у вузькому розумінні. Крок уперед у цүьому напрямі було зроблено Конституційним Судом Украйни у мотивувальній частині рімення у справі про Регламент Верховної Ради Украйни від 1 квітня 2008 p. № 4-pn/2008.

Перспективи подальших досліджень у цьому напрямі полягають у пошуку найбільш ефективних шляхів поширення інформації про зміст принципу правової визначеності у широкому розумінні.

1. Мішина Н. В. Конституційна скарга та індивідуальна заява до Європейського суду з прав людини як юридичні гарантії прав людини в Україні. Право Украӥни. 2018. № 12. С. 178-196.

2. Мішина Н. В. Гармонізація законодавства України з правовими позиціями Європейського Суду з прав людини (на матеріалах законодавства про громадські організації). Правничий часопис Донеиького університету. 2011. № 2. С. 13-21.

3. Доповідь «Верховенство права», схвалена Європейською Комісією «За демократію через право» (Венеціанською Комісією) на 86-му пленарному засіданні (Венеція, 25-26 березня 2011 p.). URL: https://www.venice.coe.int/webforms/documents/default.aspx?pdffile=CDL$\mathrm{AD}(2011) 003 \mathrm{rev}-\mathrm{ukr}$

4. Рішення Європейського суду з прав людини від 6 листопада 2008 р. у справі «Єлоєв проти України» (Заява № 17283/02). URL: https://zakon.rada.gov.ua/laws/show/ru/974_433

5. Рішення Свропейського суду з прав людини від 18 грудня 2008 р. у справі «Новік проти України» (Заява № 48068/06). URL: https://zakon.rada.gov.ua/laws/show/ru/974_442 
6. Погребняк С. П. Основоположні принципи права (змістовна характеристика). Харків: Право, 2008. 238 с.

7. Рішення Конституційного Суду України від 11 березня 2010 р. № 8-рп/2010 у справі за конституційним поданням 46 народних депутатів України щодо офіційного тлумачення термінів «найвищий судовий орган», «вищий судовий орган», «касаційне оскарження», які містяться у ст.ст. 125, 129 Конституції України. Офіційний вісник Украӥни. 2010. № 21. Ст. 882.

8. Рішення Конституційного Суду України від 22 вересня 2005 р. № 5-рп/2005 у справі за конституційним поданням 51 народного депутата України щодо відповідності Конституції України (конституційності) положень ст. 92, п. 6 розділу Х «Перехідні положення» Земельного кодексу України (справа про постійне користування земельними ділянками). Офіuійний вісник Украӥни. 2005. № 39. Ст. 2490.

9. Рішення Конституційного Суду України від 29 червня 2010 р. № 17-рп/2010 у справі за конституційним поданням Уповноваженого Верховної Ради України $з$ прав людини щодо відповідності Конституції України (конституційності) абз. 8 п. 5 ч. 1 ст. 11 Закону України «Про міліцію». Офіціийний вісник Украӥни. 2010. № 52. Ст. 1746.

10. Рішення Конституційного Суду України від 20 грудня 2017 p. № 2-p/2017 у справі за конституційним поданням 49 народних депутатів України щодо відповідності Конституції України (конституційності) п. 7 ч. 2 ст. 42 Закону України «Про вищу освіту». Oфiцiйний вісник України. 2018. № 18. Ст. 619.

11. Богачова Л. Л. Принцип правової визначеності в європейському і національному праві (змістовна характеристика). Теорія і практика правознавства. 2013. Вип. 2. URL: http://nbuv.gov.ua/UJRN/tipp_2013_2_74

12. Рішення Конституційного Суду України від 1 квітня 2008 р. № 4-рп/2008 у справі за конституційним поданням 50 народних депутатів України щодо відповідності Конституції України (конституційності) положень ч.ч. 2, 3, 4 ст. 219 Регламенту Верховної Ради України (справа про Регламент Верховної Ради України). Офіційний вісник Украӥни. 2008. № 28. Ст. 904.

DOI 10.31558/2518-7953.2019.2.4

УДК 340

I. Ф. Коваль,

в. о. декана юридичного факультету Донецького національного університету імені Василя Стуса, доктор юридичних наук, доцент

\section{РЕАЛІЗАЦІЯ ПРИНЦИПУ ВЕРХОВЕНСТВА ПРАВА ПРИ ЗАСТОСУВАННІ СПОСОБІВ ЗАХИСТУ ПРАВ ТА ІНТЕРЕСІВ}

Ключові слова: принции верховенства права, спосіб захисту, ефективний спосіб захисту, порушене право.

Забезпечення ефективного захисту прав та інтересів учасників суспільних відносин є одним 3 найголовніших завдань держави в контексті реального впровадження принципу верховенства права. Відповідно до ст. 14 Угоди про асоціа- 